\title{
Monument futures: climate change, air pollution, decay and conservation-the Wolf-Dieter Grimm-volume
}

\author{
Siegfried Siegesmund $\cdot$ Rolf Snethlage • \\ Joerg Ruedrich
}

Received: 26 April 2008/Accepted: 18 June 2008/Published online: 25 July 2008

(C) The Author(s) 2008

The weathering of historical monuments has always been a problem. In spite of the fact that most of the destruction observed worldwide on these monuments can be ascribed to war or vandalism, there are many other factors which can also contribute significantly to their deterioration. There has been a significant increase in deteriorating structures during the past two centuries. This prompted Winkler in 1983 to predict that most of these structures would be destroyed by the end of the last millennium because of predominating anthropogenic environmental influences. In addition global climate has experienced changes over a vast span of geological time during a range of timescales. The implications of future climate change on stone deterioration are also of considerable importance. Professor W.D. Grimm carried out extensive research in the laboratory on "cemetery" to study weathering processes. His results are contrary to Winkler's and the conclusion can be drawn that deterioration is a more linear process and so has not accelerated as rapidly as predicted.

In Germany, the name of Wolf-Dieter Grimm is indelibly associated with the science of natural stone, its occurrence and weathering. However, it is not only his excellent knowledge which makes him an admirable and erudite person but also his personal authority and modesty made it a pleasure to work with him. His character, his dedication to science as well his personal integrity was formed during his youth, which was a dangerous time. This

S. Siegesmund $(\bowtie) \cdot$ J. Ruedrich

Geowissenschaftliches Zentrum, Universität Göttingen,

Goldschmidtstr. 3, 37077 Göttingen, Germany

e-mail: ssieges@gwdg.de

R. Snethlage

Bayerisches Landesamt für Denkmalpflege, Zentrallabor,

Hofgraben 4, 80539 München, Germany situation is hard to understand for the post-war generation which has grown up under secure and prosperous conditions.

Wolf-Dieter Grimm was born on August, 11th 1928 in Trier, a former capital of the Roman Province of Belgica and the oldest Germany town. He was still a pupil at the age of 17 when he was recruited to military service to serve as an anti-aircraft marksman. After the war he was imprisoned for three months in American and French camps. His great diligence combined with lasting enthusiasm for research and science can be attributed to this experience.

Finally he completed school in Trier with an excellent Abitur in 1947. He then studied Geology at the University of Mainz and later at the University of Munich. In Munich, he passed the diploma examination with "sehr gut" (excellent) in May 1953 and, only two months later he took the Ph.D examination with "summa cum laude", after submitting a doctoral thesis on "Geologische und sedimentpetrographische Untersuchungen in der Oberen Süßwassermolasse zwischen Rott und Inn". The unbelievable short time between diploma and Ph.D is hard to understand nowadays and is simply due to the immense scientific content of his investigations so that his supervisor, Prof. Ferdinand Neumaier, recommended dividing the work and proposed the shorter part for the diploma thesis and the greater one for the Ph.D thesis.

Following this Wolf-Dieter Grimm left university and was in charge of the field laboratory of crude oil deep drillings in Lower Saxony and Bavaria from 1953 to 1957. However, he wanted to return to scientific work and was granted a scholarship from 1957 to 1960 at the Institute of Geology by the University of Munich, where he was later appointed assistant professor under the supervision of Prof. Albert Maucher. His lectures and research covered a wide field of sedimentary geology, crude oil geology, remote 
sensing and in particular, hydrogeology and engineering geology. In 1964 Wolf-Dieter Grimm qualified to teach at a university (Lehrbefugnis) with a habilitation thesis entitled "Schwermineralgesellschaften in Sandschüttungen, erläutert am Beispiel der Süddeutschen Molasse".

After a three year interval from 1965 to 1968 in Berlin, he returned to Munich where he was employed as scientific counsellor and professor "Wissenschaftlicher Rat und Professor" at the same Institute of Geology. There he was appointed as head of the department of Applied Geology. The focus and teaching was still on sedimentary geology, hydrogeology and engineering geology.

In the early 1980s his interest focussed on natural stone provenance and weathering phenomena. From 1980 to 1982 he conducted a huge mapping campaign on the occurrence and weathering of lithotypes in the historical centre of Munich, a project which was funded by "Stiftung Volkswagenwerk" (foundation Volkswagenwerk). From 1985 to 1990/1995 Wolf-Dieter Grimm participated in the BMFT project "Steinzerfall-Steinkonservierung" (deterioration of stone-conservation of stone). The focus of the investigation was on "Monumental Stones and its Weathering in Historical Graveyards in Germany". The essential results were integrated into the "Bildatlas wichtiger Denkmalgesteine der Bundesrepublik Deutschland", published in 1990.

Wolf-Dieter Grimm retired in 1991 but is still very intensively involved in all activities taking place in natural stone science in Germany. In particular, he is devoted to Jewish cemeteries which provide unique opportunities to study the weathering of all kinds of lithotypes in the subaerial environment unaffected by restoration interventions (Fig. 1).

Above all, Wolf-Dieter Grimm's main interest and great ability is to lecture on the relationships between natural stone science and human history. Looking at stones on monuments not only informs us about geological properties, but also makes us consider the building history of the monuments. So one can learn about the society associated with that monument and understand the complete message which monuments can convey to us.

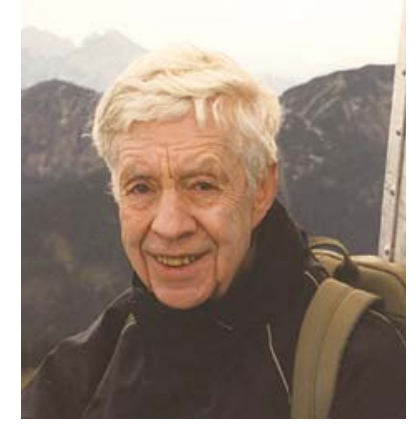

Fig. 1 Wolf-Dieter Grimm during field studies in the Alps
On his 80th birthday Wolf-Dieter Grimm is looking forward to eventually fulfilling a series of long lasting plans including, among others, a compilation of the "Gesteine der Bauten und Denkmäler Ludwigs I, König von Bayern" and the second edition of the "Bildatlas wichtiger Denkmalgesteine Deutschlands", which will be enlarged by the stones of the Neue Bundesländer and a selection of most frequent and important stones from Italy, Switzerland, Austria, France, England and other countries.

To honour Wolf-Dieter Grimm on his 80th birthday a number of papers submitted by several groups have been compiled to address the importance of the ongoing discussion on the "Future of our Monuments", mainly in Europe, and focussing on the environmental conditions of stone deterioration. Several papers have been contributed by stone weathering and atmospheric pollution network (SWAPNET). SWAPNET is a forum which brings together scientists from a range of disciplines with an interest in monument heritage and rock weathering, including stone conservators, geologists, geomorphologists, microbiologists and others. A comparable network in Germany is known as ARKUS (Arbeitskreis Erhaltung von Kulturgütern aus Stein). Neither group can accurately be described as an organisation. Rather, as their names imply, they are simply networks. They are without constitution, officers, membership, or subscription fees. The ethos of the groups is informality, and presentations tend to take the form of works in progress, which serve to promote discussion and further stimulate ongoing work. Most of these meetings incorporate a field visit to sites of conservation or heritage interest, where stone decay and restoration can be observed. Previously published volumes of SWAPNET and ARKUS proceedings are listed below.

Within the context of the mentioned networks the compilation of this new volume is dedicated to Wolf-Dieter Grimm which would not have been possible without the assistance of Derek Mottershead and Robert Inkpen of the University of Portsmouth.

Dear Wolf-Dieter Grimm, we will express our deepest gratitude to your example of both a scientist and an admirable person. We wish you for the future excellent health and say to you "ad multos annos".

Happy 80th birthday, Wolf-Dieter Grimm. Siegfried Siegesmund, Rolf Snethlage and Joerg Ruedrich.

\section{SWAPNET publications}

Smith BJ Warke PA (eds) (1996) Processes of urban stone decay. Donhead Press, Wimbledon

Weathering of building stones: papers from the stone weathering and atmospheric pollution network (SWAPNET) conference 1996 (1998) University of Portsmouth. Q Journal of Eng Geol 31(4): 301-383 
Jones MS, Wakefield RD (eds) (1999) Aspects of stone weathering, decay and conservation. Imperial College Press, London

Prikryl R, Viles HA (eds) (2002) Understanding and managing stone decay. The Karolinum Press, Prague

Viles HA, Wild LS (eds) (2003) Building stone decay: observations, experiments and modelling. Build Environ 38 (9-10): 1089-1260

Mitchell DJ, Searle DE (eds) (2004) Stone deterioration in polluted urban environments. Science Publishers, Plymouth

Smith BJ, Turkington AV (eds) (2004) Stone decay: its causes and controls. Donhead Press, Shaftesbury

Fort R, Alvarez de Burgo M, Gomez-Heras M, VasquezCalvo C (eds) (2006) Heritage, weathering and conservation, Vols 1 and 2. Taylor \& Francis, London

\section{ARKUS publications}

Siegesmund S, Vollbrecht A, Weiss T (eds) (2002) Natural stones, weathering phenomena, conservation strategies and case studies. Geol Soc Spec Pub 205 (London), pp 1-455

Siegesmund S, Viles H, Weiss T (Guest eds) (2004) Stone decay hazards. Environ Geol 46(3-4):303-526

Siegesmund S, Snethlage R, Auras M (Hrsg) (2005) Stein-Zerfall und Konservierung. Edition Verlag, Leipzig, pp 1-315
Siegesmund S, Auras M, Rüdrich J, Snethlage R (Hrsg) (2005) Geowissenschaften \& Denkmalpflege. Z Dtsch Geol Ges 156(1):1-244

Siegesmund S, Steiger M (eds) (2007) Special issue on salt decay. Environ Geol 52:185-420

Siegesmund S, Ehling A (Hrsg) (2007) Rohstoff Naturstein: Teil 1. Z Dtsch Geol Ges 158(3):349-665

Siedel H, Franzen Chr, Weise S (Hrsg) (2007) Elbsandstein. Institut für Diagnostik und Konservierung an Denkmalen in Sachsen und Sachsen-Anhalt. Dresden, pp 1-148

Auras M (Hrsg) (2006) Arkus-Tagung-Denkmalgestein Tuff. Institut für Steinkonservierung, IFS-Bericht 22, pp 1-122

Siegesmund S, Ehling A (Hrsg) (2008) Rohstoff Naturstein: Teil 2. Z Dtsch Geol Ges 158(4):667-1087

Siegesmund S, Snethlage R (eds) Denkmalgesteine: Festband Wolf-Dieter Grimm. Schr Dtsch Geol Ges 59:1312

Open Access This article is distributed under the terms of the Creative Commons Attribution Noncommercial License which permits any noncommercial use, distribution, and reproduction in any medium, provided the original author(s) and source are credited. 